\title{
Present and Importance levels leadership competencies of principals in Nepalese Schools
}

\section{Karna Bahadur Thapa}

\author{
PhD Scholar, Singhania University, Pacheri Bari, Jhunjhunu (Rajasthan) India \\ Email:thapakarna65@gmail.com
}

\begin{abstract}
Leadership competency is one of the major qualities of Principal to ensure the performance of schools. Principal is responsible to manage the overall school's environment so that s/he should have effective leadership competency. The study was explored the present level and desired level of leadership competency of principal of Nepalese schools. The study had applied Stratified proportionate sampling to select the 817 respondents from Principal, Teachers and Supervisor. The secondary level schools - government aided, community managed and institutional were selected from the Tarai, Mountain, Hill and Valley. The study found that there was significant difference between the present level and Importance level of leadership competency of Principals of Nepalese schools. The statistical analysis of t-test showed that the mean value of Importance level of competency was significantly higher than the mean value of present level of competency on the basis of types of schools and types of respondents. The study observed that there was need of improvement in present level of leadership competency of principals.
\end{abstract}

\section{KEYWORDS:}

Competency, Importance Level, Leadership, Present level, Principal

\section{INTRODUCTION}

Quality education is the product of the collective contributions of several factors including the quality leaders in the school. The movement of quality education in the country may not go longer without active participation and commitment of schools which are supposed to be the operating level of education. Likewise, the dream of imparting quality education at school may not come true unless our education system ensures the quality school leader - the school principal. Moreover, people's exposure to the quality education in the neighbouring countries and in some other developed countries has also inspired Nepalese parents and guardians to think more about the quality education to their children.

School principal constitutes the core of leadership team in the schools. It has been found that quality of principals can influence a range of school outcomes most importantly in student achievement, quality and satisfaction of teachers mainly their ability to identify and articulate school vision and mission, effective allocation of school resources, and development of organizational structure supporting to instruction and learning (Horng, Kalogridge \& Leob, 
2009). A school principal has to play a number of defined and undefined roles in a rapidly changing educational environment and is responsible for making a plethora of decisions (Fullan \& Stiegelbauer, 1991). It shows that the role of principalship demands a principal as a key figure in the school system with desired levels of professional competency. It also requires a school principal to have ability to see higher and wider than immediate problems or situations. However, for a school principal, there is no single leadership skill or set of skills presumed to be appropriate for all schools or all instructional situations (Duke in Flath, 1989). Leadership competency of principal is understood as the basic requirement to meet the quality education of schools along with education, training, exposure and experiences of principals.

The simplest meaning of competency might refer to the ability of an employee who needs to perform certain assigned tasks and responsibilities. It can be taken as general descriptions of the abilities needed to perform a role in the organization (Douglas, 1980). It also can be understood as a set of skills, knowledge, attributes as well as behaviors that are observable and measurable at the workplace, where behaviors are taken as ability to perform the activities to the standards required in the job (Boyatizis, 1982). Mostly ability indicates the state of being able to do the task, with possession of special talent and knowledge. In contrast to this, competency concerns with actions where a person's characteristics are linked to the superior performance (Esp, 1993). Competency, therefore, is an application of experiences and expertise more than just possession of knowledge and ability.

Various previous studies pertaining to school management and leadership have pointed out serious issues which need to be properly addressed if quality education is our priority and school reform dream is to be fulfilled in Nepal. Leadership issues raised by the studies are low level of efficacy of school principals (DOE, 2005), weak institutional leadership and absence of monitoring and supervision practices at schools (SESP, 2005; Bista, 2001; Sapkota,2008), indigestible and unacceptable behaviours of institutional school principals (Wagle \& Lammichhane,2006); inadequate administrative characteristics of school principals to implement TQM (Rijal,2004); and weak leadership roles of school principals (Bista \& Carney, 2007). Similarly, studies have also revealed school leadership conditions where school principals were deprived of effective training, professional development opportunity, and appropriate qualifications (Sapkota,2008; Niraula,2002; World Bank,1994), had low morale and lack of formal management education (Sapkota,2008); and lack of conceptual clarity of roles (Danish University of Education, 2001).

Considering the problem raised in previous studies, the study was focused to identify the present level and importance level of leadership competency of principals of Nepalese schools.

\section{METHOD}

The study was based on the descriptive analysis of present level and importance level of leadership competency of principals of Nepalese schools. Secondary level schools government aided, community managed and institutional were selected from Tarai, Mountain, Hill and Valley. Altogether 817 (principal $=364$, Teacher $=373 \&$ supervisor $=80$ ) respondents were selected from the study areas. Stratified proportionate sampling was employed to make 
simply representing geographical locations, and categories of the schools. Structured survey questionnaires was administered to school principals, supervisors and teachers, the competency statements was developed to measure the following leadership competencies incorporated in seven dimensions of school leadership: Instructional leadership, Learning community leadership, Micro-political leadership, Visionary leadership, Operational leadership, Strategic leadership \& Collaborative leadership. The study administered a. Competency Questionnaire for Principals (CQP), b. Competency Questionnaire for Supervisors (CQS), and c. Competency Questionnaire for Teachers (CQT) which were employed in collecting responses of principals, supervisors and teachers respectively. The study used the t-test to examine the mean differences between the present and importance levels leadership competency of principals with an intent to explore discrepancies which could be addressed in professional development models of school principals.

\section{RESULT \& DISCUSSION}

The total values of present and importance levels of leadership competency were calculated by using the compute command. The paired sample t-test was done to identify the significant difference between the present and importance levels of leadership competencies.

Table 1: Difference between total present level and importance levels leadership competencies

\begin{tabular}{|c|c|c|c|c|c|c|c|c|c|}
\hline \multicolumn{10}{|c|}{ Paired Samples Statistics } \\
\hline & & & \multirow{2}{*}{$\frac{\text { Mean }}{23.9308}$} & \multicolumn{2}{|c|}{$\mathrm{N}$} & \multicolumn{2}{|c|}{ Std. Deviation } & \multicolumn{2}{|c|}{ Std. Error Mean } \\
\hline \multirow{2}{*}{ Pair 1} & \multicolumn{2}{|c|}{ PLS } & & \multicolumn{2}{|c|}{817} & \multicolumn{2}{|l|}{4.25151} & \multicolumn{2}{|c|}{.14874} \\
\hline & \multicolumn{2}{|c|}{ ILS } & 28.3980 & \multicolumn{2}{|c|}{817} & \multicolumn{2}{|l|}{4.36604} & \multicolumn{2}{|c|}{.15275} \\
\hline & & \multicolumn{5}{|c|}{ Paired Differences } & \multirow{3}{*}{$\mathrm{t}$} & \multirow{3}{*}{ df } & \multirow{3}{*}{$\begin{array}{l}\text { Sig. (2- } \\
\text { tailed) }\end{array}$} \\
\hline & & \multirow[t]{2}{*}{ Mean } & \multirow[t]{2}{*}{$\begin{array}{c}\text { Std. } \\
\text { Deviation }\end{array}$} & \multirow[t]{2}{*}{$\begin{array}{l}\text { Std. Error } \\
\text { Mean }\end{array}$} & \multicolumn{2}{|c|}{$\begin{array}{l}95 \% \text { Confidence } \\
\text { Interval of the } \\
\text { Difference }\end{array}$} & & & \\
\hline & & & & & Lower & Upper & & & \\
\hline $\begin{array}{c}\text { Pair } \\
1\end{array}$ & $\begin{array}{l}\text { PLS - } \\
\text { ILS }\end{array}$ & $\begin{array}{c}- \\
4.46724\end{array}$ & 4.50268 & .15753 & -4.77645 & -4.15803 & $\begin{array}{c}- \\
28.358\end{array}$ & 816 & .000 \\
\hline
\end{tabular}

Source: Field survey, 2013

Analysis of data in Table 1 shows that the mean value of present level of leadership was 23.9308 against the importance level of 28.3980 as an overall ratings of all respondent groups. The result of paired sample t-test $(\mathrm{t}=28.358, \mathrm{df}=816$ and $\mathrm{P}=.000)$ shows a significant discrepancies between the present and importance levels leadership competencies of principals at $95 \%$ confidence interval.

Competencies can be understood to represent the language of performance in an organization that articulates both the expected outcomes of an individual's efforts and the manner in which these activities are carried out. It is typically used to define the behaviours of people that the organization will value and believe it help in achieving its long term goals 
(Millar, Rankin \& Neathy, 2009). Principals are also responsible to design the mission, vision and strategies activities to make the better performances of schools, teachers and students.

\section{Respondents and discrepancies between present and importance levels leadership competencies of principals}

The differences between the present and importance levels of leadership competencies were measured on the basis of demographic characteristics of respondents as well. There were three types of respondents: teachers, principals and supervisors. Tables 2, 3 and 4 presented the perceptual analysis of teachers, supervisors and principals.

\section{Teachers' perceptions on present and importance levels of leadership competencies}

Teachers' perceptions were analysed to compare the difference between the present and importance levels leadership competencies of principals. Table 2 shows mean value of present level of leadership competencies of school principals as rated by teachers was 23.9629 , importance level mean 28.5004.

Table 2: T-test on teachers' perceptions on present and importance levels leadership competencies

\begin{tabular}{|c|c|c|c|c|c|c|c|c|c|}
\hline \multicolumn{10}{|c|}{ Paired Samples Statistics } \\
\hline & & & Mean & \multirow{2}{*}{\multicolumn{2}{|c|}{$\frac{N}{373}$}} & \multicolumn{2}{|c|}{ Std. Deviation } & \multicolumn{2}{|c|}{ Std. Error Mean } \\
\hline \multirow{2}{*}{\multicolumn{2}{|c|}{$\begin{array}{c}\text { Teachers' } \\
\text { Perception }\end{array}$}} & PLS & 23.9629 & & & 4.22179 & & \multicolumn{2}{|c|}{.21860} \\
\hline & & ILS & 28.5004 & \multicolumn{2}{|c|}{373} & 4.53020 & & \multicolumn{2}{|c|}{.23457} \\
\hline & & \multicolumn{5}{|c|}{ Paired Differences } & \multirow{3}{*}{$\mathrm{t}$} & \multirow{3}{*}{ df } & \multirow{3}{*}{$\begin{array}{l}\text { Sig. (2- } \\
\text { tailed) }\end{array}$} \\
\hline & & \multirow[t]{2}{*}{ Mean } & \multirow[t]{2}{*}{$\begin{array}{c}\text { Std. } \\
\text { Deviation }\end{array}$} & \multirow{2}{*}{$\begin{array}{l}\text { Std. } \\
\text { Error } \\
\text { Mean }\end{array}$} & \multicolumn{2}{|c|}{$\begin{array}{l}\text { 95\% Confidence } \\
\text { Interval of the } \\
\text { Difference }\end{array}$} & & & \\
\hline & & & & & Lower & Upper & & & \\
\hline $\begin{array}{c}\text { Teachers' } \\
\text { Perception }\end{array}$ & $\begin{array}{r}\text { PLS } \\
\text { ILS }\end{array}$ & $\begin{array}{c}- \\
4.53746\end{array}$ & 4.38952 & .22728 & -4.98438 & -4.09055 & 19.964 & 372 & .000 \\
\hline
\end{tabular}

Source: Field survey, 2013

There was significant difference between the present and importance levels leadership competency on the basis of teachers' perceptions at $\mathrm{t}=-19.964, \mathrm{df}=372$ and $\mathrm{P}=.000$ at $95 \%$ confidence interval.

The result showed that the expected level of leadership competency was higher than the current practices of leadership. Visionary leaders can effectively run the organizations and can motivate the employees for the better performances and can increase the level of satisfaction of beneficiaries. The various previous studies have also highlighted the importance of leadership qualities. The recent focus on leadership in all kinds of organizations is an international phenomenon. It is increasingly becoming panacea of $21^{\text {st }}$ century and it has been taken as centre of excellence in almost all organizations (Bolden, 2004). 
ISSN: 2362-1303 (Paper) | elSSN: 2362-1311(Online)

JOURNAL OF ADVANCED ACADEMIC RESEARCH (JAAR)

Jan 2016

Supervisors' perceptions on present and importance levels leadership competencies

The perceptions of supervisors were also analysed by using the paired sample t-test. Table 3 shows present level leadership competency of 20.2676 as mean value, against importance level of 25.7272 .

Table 3: T-test on supervisors' perception on present and importance levels leadership competencies

\begin{tabular}{|c|c|c|c|c|c|c|c|c|c|}
\hline \multicolumn{10}{|c|}{ Paired Samples Statistics } \\
\hline & & & Mean & & & td. Deviati & & Std. Er & r Mean \\
\hline \multirow{2}{*}{\multicolumn{2}{|c|}{$\begin{array}{l}\text { Supervisors' } \\
\text { perception }\end{array}$}} & PLS & 20.2676 & & & 3.56671 & & & \\
\hline & & ILS & 25.7272 & & & 5.09306 & & & \\
\hline & & \multicolumn{5}{|c|}{ Paired Differences } & \multirow{3}{*}{$\mathrm{t}$} & \multirow{3}{*}{ df } & \multirow{3}{*}{$\begin{array}{l}\text { Sig. (2- } \\
\text { tailed) }\end{array}$} \\
\hline & & \multirow[t]{2}{*}{ Mean } & \multirow[t]{2}{*}{$\begin{array}{c}\text { Std. } \\
\text { Deviation }\end{array}$} & \multirow[t]{2}{*}{$\begin{array}{l}\text { Std. } \\
\text { Error } \\
\text { Mean }\end{array}$} & \multicolumn{2}{|c|}{$\begin{array}{l}\text { 95\% Confidence } \\
\text { Interval of the } \\
\text { Difference }\end{array}$} & & & \\
\hline & & & & & Lower & Upper & & & \\
\hline $\begin{array}{c}\text { Supervisors' } \\
\text { perception }\end{array}$ & $\begin{array}{l}\text { PLS - } \\
\text { ILS }\end{array}$ & $\begin{array}{c}- \\
5.45955\end{array}$ & 6.39172 & .71462 & -6.88196 & -4.03714 & $\begin{array}{c}- \\
7.640\end{array}$ & 79 & .000 \\
\hline
\end{tabular}

Source: Field survey, 2013

Comparison shows a significant difference between present and importance levels leadership competencies of school principals at $\mathrm{t}=7.640$, $\mathrm{df}=79$ and $\mathrm{P}=.000$ at $95 \%$ confidence interval. The t-value rejected the null hypothesis that there was no difference in perceptions of supervisor on present and importance levels of leadership competencies of principals. The mean value of importance level of leadership competency seemed to be higher than present level of leadership competency, which indicates a scope for improving existing levels of leadership competencies of principals for better school performances.

\section{Principals' perceptions on present and importance levels leadership competencies}

Principals were also asked to report on their self-evaluations on present and importance levels of leadership competencies. Table 4 pointed out mean value 24.7030 as present level of leadership competency, whereas the mean value of importance level of leadership competency was 28.8802 .

Table 4: T-test on principals' perceptions on present and importance levels leadership competencies

\begin{tabular}{|l|c|c|c|c|c|c|}
\hline \multicolumn{7}{|c|}{ Paired Samples Statistics } \\
\hline \multicolumn{2}{|c|}{} & Mean & N & Std. Deviation & Std. Error Mean \\
\hline $\begin{array}{l}\text { Principals' } \\
\text { Perception }\end{array}$ & PLS & 24.7030 & 364 & 4.00521 & \multicolumn{2}{c|}{.20993} \\
\cline { 2 - 8 } & ILS & 28.8802 & 364 & 3.78921 & .19861 \\
\hline
\end{tabular}




\begin{tabular}{|c|c|c|c|c|c|c|c|c|c|}
\hline & \multirow[t]{2}{*}{ Mean } & \multirow[t]{2}{*}{$\begin{array}{c}\text { Std. } \\
\text { Deviation }\end{array}$} & \multirow[t]{2}{*}{$\begin{array}{l}\text { Std. Error } \\
\text { Mean }\end{array}$} & \multicolumn{2}{|c|}{$\begin{array}{l}\text { 95\% Confidence } \\
\text { Interval of the } \\
\text { Difference }\end{array}$} & & & \multirow[t]{2}{*}{$\begin{array}{l}\text { Sig. (2- } \\
\text { tailed) }\end{array}$} \\
\hline & & & & & Lower & Upper & & & \\
\hline $\begin{array}{l}\text { Principals' } \\
\text { Perception }\end{array}$ & $\begin{array}{l}\text { PLS } \\
\text { - ILS }\end{array}$ & $\begin{array}{c}- \\
4.17718\end{array}$ & 4.07821 & .21376 & $\begin{array}{c}- \\
4.59754\end{array}$ & -3.75683 & 19.542 & 363 & .000 \\
\hline
\end{tabular}

Source: Field survey, 2013

There was significant difference between the present and importance levels of leadership competency on the perceptions of principals at $\mathrm{t}=-19.542, \mathrm{df}=363$ and $\mathrm{P}=.000$ at 95\% confidence interval. From the field observation, it was observed that in some cases of private institution, principals were not selected on the basis of qualities and qualifications but on the basis of quantities of investment in educational institutions. Volume of money was considered as the quality of principals and teachers who did not possess even the basic requirements of leadership qualities. Such wrong practices also made gap between the current and importance levels of leadership competencies of Principals.

Leadership is in fact a complex phenomenon intermingled with many organizational, social and personal processes. It is simply a process of influencing people, inspiring them to work towards the accomplishment of group goals, not through coercion, but through personal motivation. The importance of leadership has been widely perceived as ultimate necessity for any successful group or organizations endeavour (Curran, 1983). Mostly leadership is considered as a commitment of leader who is having a vision and possesses a mission (Caufield, 1989).

\section{Types of schools and discrepancies between present and importance levels leadership competencies of principals}

To base on school types as unit of analysis, there were three types of schools; institutional, community, and community managed schools under consideration of this study. The general objective of all types of school is similar but the special objectives are difference. The private schools are profit orientation along with the effective academic service. Institutional schools are supported by individual but community and community managed schools are partially or fully supported by the Government so their management practices may be different.

\section{Institutional Schools' perceptions on present and importance levels leadership competencies}

Table 5 shows the analysis of perceptions of all respondents towards the leadership competencies of principals in institutional schools. The mean value of present level of leadership was 24.6558 and importance level of leadership competencies was 29.6313. Mean value of importance level of leadership competency was significantly higher than present level of leadership competency. Thus the participants through their perceptions had expressed great importance of leadership competency of principals in institutional schools to better serve the stakeholders what they have promised to them. 
Table 5: T-test on institutional Schools' perceptions on present and importance levels leadership competencies

\begin{tabular}{|c|c|c|c|c|c|c|c|c|c|}
\hline \multicolumn{10}{|c|}{ Paired Samples Statistics } \\
\hline & & & \multirow{2}{*}{$\frac{\text { Mean }}{24.6558}$} & \multirow{2}{*}{\multicolumn{2}{|c|}{$\frac{N}{237}$}} & \multicolumn{2}{|c|}{ Std. Deviation } & \multicolumn{2}{|c|}{ Std. Error Mean } \\
\hline \multirow{2}{*}{\multicolumn{2}{|c|}{$\begin{array}{c}\text { Private Schools' } \\
\text { perception }\end{array}$}} & \multirow{2}{*}{$\begin{array}{c}\text { PLS } \\
\text { ILS }\end{array}$} & & & & \multicolumn{2}{|l|}{3.93023} & \multicolumn{2}{|c|}{.25530} \\
\hline & & & 29.6313 & \multicolumn{2}{|c|}{237} & \multicolumn{2}{|l|}{3.80631} & \multicolumn{2}{|c|}{.24725} \\
\hline & & \multicolumn{5}{|c|}{ Paired Differences } & \multirow{3}{*}{$\mathrm{t}$} & \multirow{3}{*}{ df } & \multirow{3}{*}{$\begin{array}{l}\text { Sig. (2- } \\
\text { tailed) }\end{array}$} \\
\hline & & \multirow[t]{2}{*}{ Mean } & \multirow[t]{2}{*}{$\begin{array}{c}\text { Std. } \\
\text { Deviation }\end{array}$} & \multirow{2}{*}{$\begin{array}{l}\text { Std. } \\
\text { Error } \\
\text { Mean }\end{array}$} & \multicolumn{2}{|c|}{$\begin{array}{l}\text { 95\% Confidence } \\
\text { Interval of the } \\
\text { Difference }\end{array}$} & & & \\
\hline & & & & & Lower & Upper & & & \\
\hline $\begin{array}{c}\text { Private } \\
\text { Schools' } \\
\text { perception }\end{array}$ & $\begin{array}{l}\text { PLS } \\
\text { ILS }\end{array}$ & $\begin{array}{c}- \\
4.9754 \\
8\end{array}$ & 4.22632 & .27453 & -5.51632 & -4.43464 & 18.124 & 236 & .000 \\
\hline
\end{tabular}

Source: Field survey, 2013

There was significant difference between the present and importance levels of leadership competency on the perceptions of participants with respect to institutional schools at $\mathrm{t}=18.124$, $\mathrm{df}=236$ and $\mathrm{P}=.000$ at $95 \%$ confidence interval. The result rejected the null hypothesis that institutional schools principals had no significant discrepancy between the present and importance levels of leadership competency of principals in the perceptions of participants.

Most of private academic institutions are of profit oriented institutions. They have to have quantity of students and have to promise desired levels of quality to their clients in order to survive in tough competition and for the profitability as well. Thus, they need to demonstrate comparatively better school performances than those of public academic institutions. Besides, these schools need to duly address parents' expectations of quality of educations as par with global context for long run survival too. In such a context, private schools are to some extent compelled to be careful and deliberatively apply some criteria for principals' recruitment and in their professional development. Some previous study had highlighted the traits of leaders.

In leadership traits- mix, Stogdill (1974) has emphasized the following as crucial traits of leaders:

Strong drive for responsibilities, Focus on completing the task, Vigor and persistence in pursuit of goals, Originality in problem-solving, Drive to exercise initiative in social settings, Self-confidence, Sense of personal identity, Willingness to accept consequences of decisions and actions, Readiness to accept interpersonal stress, Ability to influence the behaviour of others, Capacity to structure social system to the purpose in hand.

\section{Community Schools' perceptions on present and importance levels leadership competencies}

Perceptual analysis of community school in Table 6 shows that mean value of present level of leadership competency of school principals in community schools was 23.8863 
whereas mean value of importance level was 28.2714. Mean value of importance level of leadership competency was significantly higher than present level of leadership competency of principals in these schools.

Table 6: T-test on community Schools' perceptions on present and importance level leadership competencies

\begin{tabular}{|c|c|c|c|c|c|c|c|c|c|c|}
\hline & & Pair & ed Sample & Statist & & & & & \multirow{2}{*}{\multicolumn{2}{|c|}{ Remarks }} \\
\hline & & & Mean & $\mathrm{N}$ & $\begin{array}{c}\text { Std. } \\
\text { Deviation }\end{array}$ & \multicolumn{2}{|c|}{$\begin{array}{l}\text { Std. Error } \\
\text { Mean }\end{array}$} & & & \\
\hline \multirow{5}{*}{\multicolumn{2}{|c|}{$\begin{array}{l}\text { Community } \\
\text { Schools' } \\
\text { perception }\end{array}$}} & PLS & 23.8863 & 374 & 4.23356 & \multicolumn{2}{|c|}{.21891} & \multicolumn{3}{|c|}{$\begin{array}{c}\text { The mean value of ILS is } \\
\text { significantly higher than } \\
\text { PLS }\end{array}$} \\
\hline & & \multirow{2}{*}{\multicolumn{5}{|c|}{ Paired Differences }} & \multirow{4}{*}{$\mathbf{T}$} & & \multirow{4}{*}{$\begin{array}{l}\text { Sig. } \\
(2- \\
\text { tailed })\end{array}$} & \multirow{4}{*}{ Remarks } \\
\hline & & & & & & & & \multirow{3}{*}{ df } & & \\
\hline & & \multirow[t]{2}{*}{ Mean } & \multirow[t]{2}{*}{$\begin{array}{c}\text { Std. } \\
\text { Deviation }\end{array}$} & \multirow[t]{2}{*}{$\begin{array}{l}\text { Std. } \\
\text { Error } \\
\text { Mean }\end{array}$} & \multicolumn{2}{|c|}{\begin{tabular}{|c|} 
95\% Confidence \\
Interval of the \\
Difference
\end{tabular}} & & & & \\
\hline & & & & & Lower & Upper & & & & \\
\hline $\begin{array}{l}\text { Community } \\
\text { Schools' } \\
\text { perception }\end{array}$ & $\begin{array}{c}\text { PLS } \\
- \\
\text { ILS }\end{array}$ & $\begin{array}{c}- \\
4.38516\end{array}$ & 4.20850 & .21762 & $\begin{array}{c}- \\
4.81307\end{array}$ & $\begin{array}{c}- \\
3.95725\end{array}$ & 20.151 & 373 & .000 & $\begin{array}{l}\text { Null } \\
\text { hypothesis } \\
\text { rejected }\end{array}$ \\
\hline
\end{tabular}

Source: Field survey, 2013

There was significant difference between the present and importance levels of leadership competency on the perceptions of participants of community schools at $t=20.151$, $\mathrm{df}=373$ and $\mathrm{P}=.000$ at $95 \%$ confidence interval. The result rejected the null hypothesis that there was no significant discrepancy between the present and importance levels leadership competencies of school principals.

Chen (2002) undertook a similar study in regard to the competency of vocational high school principals in Taiwan. This study was conducted among 192 high school principals as research subjects, dividing the leadership competencies into leadership roles, values and skills of school principals. This study has categorized prosperity, sense of accomplishment, career satisfaction, equal opportunity, independence, good health personal development, ethics, selfesteem, recognition, and maturity as leadership values; leadership role has contained influential roles (visionary, task giver, motivator, ambassador, liaison ), informational roles (monitor, disseminator, advocate), and decisive roles (change agent, disturbance handler, resource allocators, negotiators).

\section{Community managed Schools' perceptions on present and importance levels leadership competencies}

Participants of Community managed schools were also asked to rate their perceptions on the present and importance levels of leadership competency of principals in these schools. Table 7 shows that the mean value of present level of leadership competency was 25.0250 
whereas mean value of importance level of leadership competency was 28.1499. Mean value of importance level of leadership competency was significantly higher than present level of leadership competencies school principals.

Table 7: T-test on community managed Schools' perceptions on present and importance levels leadership competencies

\begin{tabular}{|c|c|c|c|c|c|c|c|c|c|c|c|}
\hline \multicolumn{10}{|c|}{ Paired Samples Statistics } & \multirow{2}{*}{\multicolumn{2}{|c|}{ Remarks }} \\
\hline & & & Mean & $\mathbf{N}$ & $\begin{array}{r}\text { Std. } \\
\text { Deviati }\end{array}$ & & & $\begin{array}{l}\text { d. Err } \\
\text { Mean }\end{array}$ & & & \\
\hline \multirow{2}{*}{\multicolumn{2}{|c|}{$\begin{array}{c}\text { Community } \\
\text { managed Schools' } \\
\text { perception }\end{array}$}} & PLS & 25.025 & 126 & 4.0635 & & & .36201 & & \multirow{2}{*}{\multicolumn{2}{|c|}{$\begin{array}{l}\text { The mean value of } \\
\text { ILS is significantly } \\
\text { higher than PLS }\end{array}$}} \\
\hline & & ILS & 28.149 & $\begin{array}{ll}9 & 126\end{array}$ & 4.5424 & & \multicolumn{3}{|c|}{.40467} & & \\
\hline & & \multicolumn{6}{|c|}{ Paired Differences } & \multirow{3}{*}{$\mathbf{t}$} & \multirow{3}{*}{ df } & \multirow{3}{*}{$\begin{array}{c}\text { Sig. } \\
(2- \\
\text { tailed })\end{array}$} & \multirow{3}{*}{ Remarks } \\
\hline & & \multirow[t]{2}{*}{ Mean } & \multirow[t]{2}{*}{$\begin{array}{c}\text { Std. } \\
\text { Deviation }\end{array}$} & \multirow{2}{*}{$\begin{array}{l}\text { Std. } \\
\text { Error } \\
\text { Mean }\end{array}$} & $\begin{array}{r}95 \% \text { CoI } \\
\text { Interva } \\
\text { Diffe }\end{array}$ & $\begin{array}{l}\text { nfide } \\
\text { l of } t \\
\text { rence }\end{array}$ & & & & & \\
\hline & & & & & Lower & $\mathbf{U p}_{\mathbf{p}}$ & & & & & \\
\hline $\begin{array}{l}\text { Community } \\
\text { managed } \\
\text { Schools' } \\
\text { perception }\end{array}$ & $\begin{array}{c}\text { PLS } \\
- \\
\text { ILS }\end{array}$ & $\begin{array}{c}- \\
3.12483\end{array}$ & 4.12299 & .36731 & $\begin{array}{c}- \\
3.85178\end{array}$ & \multicolumn{2}{|c|}{$\begin{array}{c}- \\
2.39789\end{array}$} & $\begin{array}{c}- \\
8.507\end{array}$ & 125 & .000 & $\begin{array}{l}\text { Null } \\
\text { hypothesis } \\
\text { rejected }\end{array}$ \\
\hline
\end{tabular}

Source: Field survey, 2013

There was significant difference between present and importance levels of leadership competency at $\mathrm{t}=-8.507, \mathrm{df}=125$ and $\mathrm{P}=.000$ at $95 \%$ confidence interval on perceptions of community managed schools' participants. The result rejected the null hypothesis that there was no significant difference between the present and importance levels of leadership competencies of principals in community managed schools. A similar type of study was conducted in international market which supports to logically discuss the findings of this study.

Noureen (2001) a Ph.D. researcher in university of Punjab has undertaken a research with a view to relate management competencies of school principals to school effectiveness in the year 2001. This study was conducted among 200 schools and 800 school teachers of secondary level schools in Punjab province of Pakistan. The researcher has reached the following conclusions as revealed by the study:

i. The more experienced heads were more competent as compared to their novice counterparts.

ii. Professionally more qualified heads showed higher level of management competencies.

iii. The relationship between school heads management competencies and school effectiveness was found positive and statistically significant.

iv. There was significant difference between the management competencies of the school heads in urban and rural locations; urban school heads were reported more 
competent than rural school heads.

v. The relationship between management courses attended by the school heads and management competencies was found positive, and statistically significant.

vi. No significant difference was observed between the perceptions of highly effective school heads and their teachers' perceptions about heads' management competencies; whereas the heads of low effective school heads perceived themselves highly competent as compared to their teachers' perceptions.

\section{CONCLUSION}

Statistically, a significant discrepancy was observed in the perceptions of respondents regarding the importance and present levels of leadership competencies of school principals. Besides that, the result of categorical data analysis also depicted the significant discrepancies between these importance and present levels of principals' competencies in all types of schools and groups of participants as well. There was no association in the perceptions of school teachers, principals and supervisors with respect to Present level, importance level and discrepancies of competencies in all three types of schools. In total, principals claimed themselves to be more competent at leadership roles and also pointed out higher importance of all their leadership competencies in future than those of school teachers and supervisors. However, discrepancies between present and importance levels of competencies were found to to be significant in the ratings of school principals in all schools. School teachers stood at middle in ratings their perceptions of leadership competencies of school principals in terms of present, importance levels and discrepancies as well. School supervisors with respect to leadership competencies of school principals seemed to be quite different in ratings of present and importance levels of given competencies. In all three types of schools, they rated the present levels of leadership competencies of principals at minimum and also underrated the given leadership competencies of school principals in school leadership. Their perceptions towards the importance of leadership competencies in school leadership has indicated the role conflict in their perspective to the school leadership. The results of this study pointed out the ideal or importance levels of leadership competencies of principals at the highest level in institutional schools, second highest in community and lowest in the community managed schools. Leadership competencies of school principals at present could be seen the highest at community managed schools, and then intuitional and community schools. Under different contexts of these three schools, discrepancies of leadership competencies between present and importance levels were found to be the highest in institutional, and the lowest in community managed schools.

To conclude the findings of study, it seems that school leadership competencies in all types of schools were not satisfactory and adequate to address the growing quality expectations of learners and parents of schools in Nepal. As the discrepancies of competencies exist in all types of schools, there could be scope for professional development initiations especially for enhancing their competencies for the accomplishment of desired out comes at school performance. 


\section{REFERENCES}

Bista, M. B. (2001). A study of class room practices in secondary schools in Nepal. Nepal Secondary Education Project, Ministry of Education, Nepal.

Bista, M. \& Carney, S. (2007). Analyzing Capacity in Ministry of Education: A Case from Nepal, Journal of Education for International Development. Sep. 2007, 3:1.Retrived from: http//www.equip123.net/JEID/articles/5/analyzing capacity in ministry of Ed.pdf

Bolden, R. (2004). What is leadership? Research Report 1.Leadership South West University of Exeter.

Boyatizis, R.E. (1982). The competent manager: a model for effective performance.

Chen, J. (2002). Leadership competencies of vocational high schools in Taiwan. A study report. College of Liberal Education, Shu-Te University, Taiwan.

Danish University of Education (2001). Capacity building for educational Improvement: An institutional analysis of the MOES of Nepal. Danish University, International program for education and development study and resource centre, Kathmandu, Nepal.

Department of Education, Nepal (2005). Detail Study on Head Teacher Efficacy and School Improvement. Ministry of Education, Government of Nepal.

Esp, D. (1993). Competences for school managers. Kogan page Ltd, London.

Fullan, M \& Stiegelbauer, S, 1991, the new meaning of educational change, London, Cassell. In Hill,P. W. (n.d.). What head teaches need to know about teaching and learning. National College for School Leadership

Niraula, T.N. (2002). Professional development needs of secondary school head masters in Nepal. Doctoral dissertation, Teachers' college, Columbia University.

Noureen, G. (2001). A study on the relationship between management competencies of principals and school effectiveness. Doctoral dissertation. Institute of education and Research, University of Punjab, Lahore

Rijal, C. P. (2004). Leadership readiness to implement total quality management in the Nepalese secondary schools.(Unpublished Doctoral dissertation).School of Education, Kathmandu University.

Secondary Education Support Program, SESP (2005.Status Report. Department of Education, Ministry of Education, Nepal.

Sapkota, S.K. (2008). School leadership in public schools of Nepal. Unpublished Master's thesis. School of Education, Kathmandu University.

Stogdill, R.M. (1974). Hand Book of Leadership: A Survey of Theory and Research. New York: Free Press. In Bolden, R.(2004). What is leadership? Research Report 1. Leadership, South West University of Exeter.

Wagle, M.P., \& Lamichhane, S. (2006). Oppression in Private School. The Himalayan Times (2063B.S. Paush 28).

World Bank (1994). Critical issues in secondary education and options for reform. Executive summary, vol. 1, April 11.South Asia Country Department, Population and HR Division. 
ISSN: 2362-1303 (Paper) | elSSN: 2362-1311(Online) 